\title{
China's Domestic Law on the Exploration and Development of Resources in Deep Seabed Areas
}

\author{
Chelsea Zhaoxi Chen
}

The "Law of the People's Republic of China on Exploration for and Exploitation of Resources in the Deep Seabed Area" (the law, or the Deep Seabed Law) was adopted on 26 February 2016 and went into force on 1 May 2016. ${ }^{1}$ This represents China's first special law dealing with the exploration for and exploitation of deep seabed resources. "Resources" here however was not defined. It is speculated that currently the definition only refers to non-living resources such as minerals but is intentionally silent regarding living seabed resources. This limitation to non-living resources in China's Deep Seabed Law is inferred from the limitation of the 1982 United Nations Convention on the Law of the Sea (UNCLOS, or the Convention), and the definition given thereunder for the term "resources".

In addition, the law applies to activities conducted by Chinese entities in the Area. Pursuant to Article 1(1) of the Unclos, "Area" means the seabed and ocean floor and subsoil thereof, beyond the limits of national jurisdiction. In other words, the applicable area of the Deep Seabed Law is not the traditional "within the territory of the People's Republic of China and other sea areas under the jurisdiction of China". ${ }^{3}$ Instead, it aims to effectively govern the behaviour of Chinese citizens, legal persons or organisations from territories outside the

1 Zhonghua Renmin Gonghe Guo Shenhai Haidi Quyu Ziyuan Kantan Kaifa Fa (中华人民 共和国深海海底区域资源勘探开发法) [Law of the People's Republic of China on the Exploration and Development of Resources in Deep Seabed Areas] (promulgated by Standing Committee of the National People's Congress, February 26, 2016, effective May 1, 2016) (Chinalawinfo) [hereinafter Deep Seabed Law], https://isa.org.jm/nld/china.

2 Article 133 of UNCLOS states, "For the purposes of this Part: (a) "resources" means all solid, liquid or gaseous mineral resources in situ in the Area at or beneath the seabed, including polymetallic nodules; (b) resources, when recovered from the Area, are referred to as "minerals"'

3 Article 2 of Zhonghua Renmin Gonghe Guo Haiyang Huanjing Baohu Fa (中华人民共和 国海洋环境保护法)[Marine Environmental Protection Law of the People's Republic of China] (promulgated by the National People's Congress, Aug. 23, 1982, amended Dec. 25, 
jurisdiction of China and other countries, i.e. a law governing extraterritorial issues.

Prior to the adoption of the Deep Seabed Law, China had already adopted laws, rules and regulations regarding the exploration for, and development of, oceanic mineral resources located within marine areas under its national jurisdiction:

- The Mineral Resources Law of the People's Republic of China, adopted at the 15th meeting of the Standing Committee of the Sixth National People's Congress on 19 March 1986, and revised on 29 August 1996;

- Rules for Implementation of the Mineral Resources Law of the People's Republic of China, promulgated by Decree No. $15^{2}$ of the State Council on 26 March 1994, and effective as of the date of promulgation;

- Marine Environmental Protection Law of the People's Republic of China, adopted at the twenty-fourth session of the Standing Committee of the Fifth National People's Congress on 23 August 1982, effective as of 1 March 1983, and further revised on 25 December 1999;

- Administrative Regulation on the Prevention and Treatment of the Pollution and Damage to the Marine Environment by Marine Engineering Construction Projects, promulgated by the State Council on 25 March 2010 and entered into force on the same day.

Inter alia, the laws and regulations mentioned above govern only waters under Chinese jurisdictions. Therefore, the Deep Seabed Law is an innovative piece of legislation which completes China's legal system governing deep-sea mining activities.

This chapter intends to demonstrate how China has complied with the UNCLOS by the enactment of the Deep Seabed Law. It also aims to review how the law regulates deep-sea mining activities outside the territorial waters of any nation. In the following parts, Section 2 begins by introducing the favourable national circumstances leading towards its enactment. Section 3 then proceeds to answer two questions: why does China need this law and why in 2016. The main part of this chapter compares China's Deep Seabed Law with laws of other countries with respect to (a) application scope, (b) competent national authority, (c) State sponsorship scheme, (d) rights and obligations of contractors, (e) environmental protection mechanism and (f) information sharing and cooperation respectively (Section 4). Section 5 comments on the three core legislative intents of the law, namely to control deep-sea mining activities, to protect lawful rights and interests, and to prepare for greater capability.

1999), English translation available at: http://english.court.gov.cn/2016-04/15/content_24562 836.htm. 
Section 6 examines the significance of the Law, while Section 7 concludes by evaluating its implementation and impact on China's other areas of law.

\section{National Circumstances Paving the Way for the Enactment of the Deep Seabed Law}

Being consistent with Chinese legislative tradition, the Deep Seabed Law is a short but concise piece of legislation consisting of 7 chapters with 29 articles. It is the first law governing activities of exploration and exploitation of the seabed, ocean floor, and subsoil thereof beyond the limits of China's national jurisdiction. Preliminary research work for the drafting of the law has been conducted since 2011, and upon completion of the preparatory phase, the government proceeded with the legislative protocol straight away. ${ }^{4}$ During the two rounds of voting at the National People's Congress (NPC), the NPC Standing Committee deliberated on the first draft of the law in its bimonthly session in October 2015, which contained 32 articles. The draft was then further revised and submitted to the 19th Session of the Standing Committee of the Twelfth National People's Congress for a second reading in February 2016. ${ }^{5}$ This led to the law being adopted on 26 February 2016, and only 3 articles were deleted for its final version, which indicated that the law had been well received and

4 Legislative procedure of the National People's Congress (NPC) involves three stages: (1) introduction of Bills; (2) deliberations of Bills; (3) passage and promulgation of laws. Bills sponsored by the NPC Standing Committee, State Council, and/or the NPC special committees such as the NPC Environmental and Resources Special Committee which in this case sponsored the Deep Seabed Law, usually are introduced through the Presidium and are able get to the NPC legislation agenda automatically. A formal deliberation begins with an introduction to the bill at a NPC plenary session. Either the NPC Standing Committee or the sponsor explains the bill to the full session of the NPC.

5 Upon being introduced, the bill was to receive examination by the deputations, relevant special committees, the Legislative Work Committee respectively. Deputations' consideration of the bill submitted to the Standing Committee is the basic form of deliberation. The sponsor's representatives are expected to be present at the deputation meetings, to listen to their opinions and respond to inquiries about the bill. It is intended to let examiners and sponsors communicate directly. The Legislative Work Committee views the bill unitarily on the basis of the result of deputation and special committee examinations. A report on the deliberation, along with a revised draft, then goes back to the Presidium. The report is expected to include a description of major controversies, an assessment on the maturity and feasibility of the legislation, and an explanation to the amendments if there is any. The report and the revised draft, after viewed by the Presidium, will be printed and distributed for another round of deputations' consideration. The Legislative Work Committee would revise the draft again according to the deputations' suggestions. The output is then submitted by the Presidium to a plenary vote. It would be passed to become a law if the majority goes for it. 
did not face any major controversies; thus, few changes had been made to the original proposal. Several favourable national circumstances have contributed to its smooth and speedy passing.

\subsection{Support from Top Leadership}

China is a coastal state with 2.997 million square kilometres of ocean area. ${ }^{6}$ However, China is not yet viewed as a strong maritime power. The national strategy of marine development began on 8 November 2012 when Hu Jintao, the then general secretary of the Central Committee of the Communist Party of China (CPC) and Chinese president, delivered a work report to the 18th CPC National Congress. ${ }^{7}$ The report vowed to develop China into a "maritime power": "We should enhance our capacity for exploiting marine resources, develop the marine economy, protect the marine ecological environment, resolutely safeguard China's maritime rights and interests, and build China into a maritime power." In addition, the current Chinese president, Xi Jinping, has also stressed the importance of marine power development and of establishing China's marine economy as a new growth point in his speech addressing the 8th Group Study for the Political Bureau of the Central Committee of the CPC in 2013. ${ }^{8}$ Thus, with firm support from the top leadership, the Twelfth National People's Congress efficiently moved to adopt the Deep Seabed Law.

\subsection{Four Exploration Contracts from the ISA}

A second factor that facilitated the passing of the Deep Seabed Law was that China is becoming increasingly active with international seabed mining activities. The China Ocean Mineral Resource R\&D Association (COMRA) was established in 1990 and has since been instrumental in spearheading China's ambitions for deep seabed development. COMRA is a governmental organisation directly under the guidance of the Ministry of Natural Resources. ${ }^{9}$ It

6 中国的海洋国土面积有多大[How big is China's Ocean Area],ChinaIRN.com, Oct 18, 2018, http://www.chinairn.com/news/20181018/141721227.shtml.

7 中国共产党十八大报告全文 [Full Report to the 18th CPC Congress], China Daily, August 01, 2013, http://www.mj.org.cn/zsjs/wsxy/201211/t20121126_145927.htm.

8 Sheng Yueyue (沈跃跃), Renzhen Xuexi Quanmian Shishi Shenhai Haidi QUyu Ziyuan Kantn Kaifa Fa (认真学习全面实施深海海底区域资源勘探开发法) [Study and Implementation of the law on Exploration for and Exploitation of Resources in the Deep Seabed Area], People's Congress of China Journal (中国人大) 8 (May 2016); 关于“海洋”十九大报告提到 这些内容[Highlights of the1gth CPC Congress Report in relation to marine industry with full text attached], Sohu News, https://www.sohu.com/a/198905707_726570.

9 COMra used to be under the guidance of the State Oceanic Administration which is now a part of the Ministry of Natural Resources. China's Ministry of Natural Resources was newly formed in March 2018. 
undertakes both research and commercial activities related to exploration and exploitation in the Area, in accordance with the applicable provisions of UNCLOS and the 1994 Agreement relating to the Implementation of Part XI of UNCLOS (the Implementation Agreement). COMRA was registered as one of the seven pioneer investors for the preparatory committee for the International Seabed Authority (ISA, the Authority) and the International Tribunal for the Law of the Sea (ITLOS) in 1991.

Via COMRA, China signed its first exploration contract for polymetallic nodules with the ISA in 2001, and has since acquired the exclusive exploration rights as well as preferential rights for exploitation with respect to those minerals in the contracted seabed area. In 2011 and 2014, COMRA signed additional exploration contracts for polymetallic sulphides and cobalt-rich ferromanganese crusts with the Authority, respectively.

Meanwhile, Chinese scientists have predicted that China is facing a severe problem related to a major mineral shortage. By 2020, 39 out of 45 major types of minerals produced within the nation could be inadequate for meeting China's domestic demand. ${ }^{10}$ In order to supply the country's rising demand for copper, cobalt, gold and the rare-earth elements that are vital in the manufacturing of smartphones and other high-tech products, China Minmetals Corporation, a state-owned company and now the country's largest metals trader, ${ }^{11}$ has also delved into deep-sea mining research and development. In 2015, the ISA authorised an exploration contract, a 72,745 square kilometre (28,087 sq. mile) permit in the Pacific Ocean, to China Minmetals. Then on 12 May 2017, a contract for exploration for polymetallic nodules between the ISA and China Minmetals Corporation was signed on 17 May 2017. Together with the COMra contracts, China is now a Party State which sponsors the largest number of seabed exploration contracts issued by the Authority covering all three types of deep-sea minerals (i.e., polymetallic nodules, polymetallic sulphides and cobalt-rich ferromanganese crusts).

The exploration and exploitation of resources in the Area are considered a difficult, risky, pioneering, and comprehensive project. It is also an international undertaking of tremendous political, economic, and strategic significance.

\footnotetext{
10 Zhang Xianglan \& Ye Quan (张湘兰\&叶泉), Zhongguo Guoji Haidi Quyu Kaifa Lifa Tanxi (中国国际海底区域开发立法探析) [An Analysis on China's Legislation on Internationl Seabed Area], 8 Law Science Magazine (法学杂志) 73 (2012).

11 China Minmetals Corporation is China's biggest metal ore mining company and metallurgical engineering service provider. China Minmetals is born out of the strategic merger of the former China Minmetals Limited Company (founded in 1950) and the Metallurgical Construction Corporation of China (MCC Group, founded in 1982) in 2015. Both were state-owned and Fortune Global 500 companies.
} 
With the perspective that more national entities would assume a part in the project, and more ISA contracts would be signed in the future, China's central government was in need of a competent legal tool to strengthen its supervision and management of activities conducted in the Area, as well as to ensure compliance of entities operating in the Area. The promulgation of the Deep Seabed Law fulfils China's sponsoring State obligations and protects the legal interests of the sponsored contractors.

\subsection{Technological Advancement}

Thirdly, China has seen remarkable achievements in deep-sea exploration technology. For example, the successful launch of the "Three Dragons" equipment system symbolised China's ambition to make full use of the deep seabed areas.

Representing a technological milestone and an important part of the national marine strategy, the "Three Dragons System" consists of:

- Human Occupied Vehicles (Hovs) known as "Jiaolong";

- Autonomous/Unmanned Underwater Vehicles (AUVs) called the "Qianlong" series; ${ }^{12}$ and

- Remotely Operated Vehicles (ROvs) designated the "Sea Dragon" series. ${ }^{13}$

Benefiting from a variety of technological advancements, China has undertaken over 50 ocean voyages to conduct comprehensive surveys and scientific research on the deep sea environment and has acquired valuable first-hand knowledge in relation to mining activities in the Area. ${ }^{14}$ The latest 52 nd ocean voyage set sail from Qingdao on 10 December 2018 and finished on 25 July 2019. Equipped with the most advanced "Jiaolong", "Qianlong No. 3" and "Sea Dragon No. 3", this voyage was an important task and a major part of China's marine development project under the 13th Five-Year Plan for economic and social development (2016-2020). The voyage was designed in two parts consisting of a total of 228 days. Part A was 150 days, covering the Indian Ocean and Atlantic Ocean, conducting surveys of the marine environment, prospecting biological genetic resources, and collecting environmental baseline data and samples in the surveyed area. Part B was 78 days, mainly conducting a comprehensive investigation of polymetallic sulphides in the southwest Indian Ocean in order

12 According to comra website information, China now has 'Qianlong No. 1', 'Qianlong No. 2' and 'Qianlong No. 3' in operation. http://www.comra.org/2019-02/11/content_4066o825 .htm.

13 Ibid. 'Sea Dragon No. 1', 'Sea Dragon No. 2' and 'Sea Dragon No. 3'.

$14 S e$ “大洋一号”起航执行中国大洋 52 航次科考任务 [“Ocean No.1” sets sail to carry out China's 5 nd oceanic voyage for scientific research mission], People's Daily, December 11, 2018, http://www.comra.org/2018-12/11/content_40608711.htm. 
to collect samples and information to further comprehend the resources and environmental status. ${ }^{15}$

Above all, technological developments have provided a solid foundation for expanded research and served as important precondition for China's legislation concerning the exploration and development of resources located in the international seabed area.

\subsection{Why Does China Need the Deep Seabed Law?}

The most important reason for China to pass the Deep Seabed Law was to proactively fulfil its obligations under international laws. China ratified UNCLOS in 1996 that consisted of three layers of obligations of which China is required to comply under the Convention: as a State Party, as a sponsoring State, and as a responsible member of the international community.

First, the Deep Seabed Law fulfils China's responsibilities as a State Party. This originates from Article 139, paragraph 1 of UNCLOS, which establishes the obligations of States Parties. Pursuant to that Article, States Parties shall have the responsibility to ensure that activities carried out by their sponsored contractors in the Area shall be in conformity with Part XI of UNCLOs. ${ }^{16}$ Additionally, Article 153, paragraph 4 of Part XI provides that the obligation of the States Parties in accordance with Article 139 entails "taking all measures necessary" to ensure compliance by the sponsored contractor, and Annex III, Article 4, paragraph 4 of UNCLOS further states that such sponsoring States have the "responsibility to ensure" that "laws and regulations" should be adopted "within their legal systems". 17 The purpose of these provisions is to achieve a result where the obligations set out in the Convention, a treaty under international law which binds only States Parties thereto, are fully complied with by entities that are subjects of domestic legal systems.

The process of how international agreements become a part of domestic laws of a sovereign state varies from State to State. Some States follow a monist

\footnotetext{
15 利器加持: 中国大洋第 52 航次启航[Equipped with powerful tools, the 5 2rd ocean voyage embarks], Science and Technology Daily, December 11, 2018, http://www.comra .org/2018-12/11/content_40608572.htm.

16 Part XI entitled 'the Area' containing Articles 133-191 of the UNCLOS, governs all activities taking place in the Area, available at: http://www.un.org/Depts/los/convention_agree ments/texts/unclos/closindxAgree.htm.

17 Annex III of UNCLOS, available at: http://www.un.org/Depts/los/convention_agree ments/texts/unclos/closindxAgree.htm.
} 
system where treaties can become domestic law without incorporation, such as the Netherlands and France. Moreover, domestic courts in these countries could directly apply self-executing treaties if the provisions are considered sufficiently self-explanatory and these countries generally have constitutional provisions to provide legitimacy. In contrast, dualist states such as the United Kingdom require all treaties to go through a process of incorporation of international law before treaties can have any domestic legal effects.

China's constitution is silent concerning the relationship between international treaties and domestic laws. However, Judicial practice has demonstrated that China follows a treaty ratification method somewhere between these two extremes. Automatic incorporating takes place only when the domestic law contains specific provisions. For example, Article 142 of China's General Principles of the Civil Law has indicated that "If any international treaty concluded or acceded to by the People's Republic of China contains provisions differing from those in the civil laws of the People's Republic of China, the provisions of the international treaty shall apply, unless the provisions are ones on which the People's Republic of China has announced reservations." 18 Therefore, with respect to civil laws, when international treaties contradict domestic laws, international laws prevail. In other cases, China incorporates international treaties by passing a law that gives effect to that treaty at the domestic level, such as in the case of incorporating UnCLos. The enactment of the Deep Seabed Law is China's response to its "responsibility to ensure" in order to comply with its requirements as a State Party.

Second, the enactment of the Deep Seabed Law aims to relieve China from its liability as a sponsoring State, namely, the consequences of a breach of the sponsoring State's primary obligations. In practical terms, as pointed out by Ximena Hinrichs Oyarce, the issue to be considered is whether, in the event of a single incident causing damage to the Area or its resources, the liability either of the sponsoring State or of the sponsored contractor would arise. (See Ximena Hinrichs Oyarce, Sponsoring States in the Area: Obligations, Liability and the Role Development States, Marine Policy 95 (2018) 317-323) The special advisory opinion of the Seabed Disputes Chamber of ITLOS in 2011 (the Advisory Opinion) has given clarification to that point. The Advisory Opinion indicates that the failure of a sponsoring State to carry out its obligations gives rise to liability only when such failure results in damage by the contractor. The sponsoring State is absolved from liability if it has taken the necessary and appropriate measures.

18 General Principles of the Civil Law, available at: http://www.npc.gov.cn/englishnpc/ Law/2007-12/12/content_1383941.htm. 
However, this exemption does not apply automatically, as the "responsibility to ensure" is an obligation of "due diligence". For it to apply, the sponsoring State must have taken "all necessary and appropriate measures to secure effective compliance" by the sponsored contractor with its obligations, ${ }^{19}$ while the exception does not apply to the failure of the sponsoring State to carry out its direct obligations. ${ }^{20}$

China is a sponsoring State for four ISA contracts. The promulgation of the Deep Seabed Law and the implementation of administrative control with regard to the exploration and exploitation of deep seabed resources therefore serves two functions. It is a measure not only through which Chinese government could ensure compliance by its sponsored contractors (currently COMRA and China Minmetals) with their obligations under the relevant contracts and UNCLOS, but also an indispensable conditions that China must satisfy if it intends to be exempted from liability for damage.

Third, the Deep Seabed Law reflects China's pledge to protect the marine environment as a rule-abiding and responsible member of the international community. Both UNCLOS Part XII and the Authority's three regulations governing mineral-related exploration activities have provided special emphasis on protecting the marine environment from any harmful effects arising from mining and exploration activities. ${ }^{21}$ The Area and its resources are the common heritage of mankind; thus, all rights associated with the resources of the

19 Responsibilities and Obligations of States with respect to activities in the Area, Advisory Opinion, 1 February 2011, ITLOS Reports, 2011 (hereinafter Responsibilities and obligations of States), pp. 6o-61, para. 186.

20 Id. Responsibilities and obligations of States, p. 65, para. 207. The Advisory Opinion also indicates that the most important direct obligations of sponsoring States are: 1) the obligation to assist the ISA in the task of controlling activities in the Area pursuant to article 153(4) of UNCLOS; 2) the precautionary approach based on Principle 15 of the Rio Declaration, requiring actions where scientific evidence is insufficient but "where there are plausible indications of potential risk"; 3) best environmental practices (i.e., more than just best available technology); 4) the obligation to take measures to ensure the provision of guarantees in the event of an emergency order by the ISA for protection of the marine environment; 4) requirements to provide recourse for compensation; and 5) the obligation to conduct an environmental impact assessment. These "direct obligations" exist independently of the obligation "to ensure". The "obligation of ensuring compliance" (Article 139 of UnCLOS) is a duty of "due diligence". Compliance with these direct obligations can be considered a relevant factor in determining whether a State has acted with due diligence. Responsibilities and obligations of States, p. 44, para. 122.

21 To date, the ISA has issued Regulations on Prospecting and Exploration for Polymetallic Nodules in the Area (adopted 13 July 2000) which was later updated and adopted 25 July 2013; the Regulations on Prospecting and Exploration for Polymetallic Sulphides in the Area (adopted 7 May 2010) and the Regulations on Prospecting and Exploration for Cobalt-Rich Crusts (adopted 27 July 2012). 
Area are vested in mankind as a whole. Therefore, protecting the marine environment of the Area is essentially for the benefit of all mankind and future generations. Adopting the Deep Seabed Law reflects the strong commitment and effort that China is making in order to maintain the international seabed order, to promote the sustainable and healthy development of the marine industry, and to advocate for the peaceful exploitation of deep-sea resources.

\subsection{Why Was It Promulgated in 2016?}

While China has become an active State Party to UnCLOs, it was not among the first few countries to pass national legislation to incorporate UNCLOS requirements. Prior to the enactment of the Deep Seabed Law in March 2016, 16 countries throughout the world had already adopted legislation (Act or Law) governing their engagement in seabed mineral activities undertaken in the Area. Consistent with the timing of their promulgation and against the benchmark event of UNCLOS entering into effect, the legislation may be divided into two specific groups (see table below).

One could say that the promulgation of the Deep Seabed Law represented a way for China to follow the regulatory trend. However, a crucial reason for the enactment of the Deep Seabed Law in 2016 was based primarily on the fact that one of China's exploration contracts was due to expire.

Among the twenty-nine 15-year contracts the ISA has entered into for exploration for polymetallic nodules, polymetallic sulphides and cobalt-rich ferromanganese crusts in the deep seabed, China has acquired the following four contracts:

- 2001, COMRA, polymetallic nodules, $75,000 \mathrm{~km}^{2}$ of the North-east Pacific Ocean;

- 2011, COMRA, polymetallic sulphides, $10000 \mathrm{~km}^{2}$ of the South-west Indian Ocean;

- 2014, COM RA, cobalt-rich ferromanganese crusts, $3000 \mathrm{~km}^{2}$ of the North-east Pacific Ocean;

- 2017, China Minmetals, polymetallic nodules, $72,745 \mathrm{~km}^{2}$ of the East Pacific Ocean

As provided for in Regulation 26 of the 2000 Regulations on Prospecting and Exploration for Polymetallic Nodules in the Area (amended and adopted 25 July 2013), the duration of a plan of work for an exploration contract is for 15 years. Upon expiration of that period, the contractor shall apply for a plan of work for exploitation, unless the contractor has already done so, or has obtained an extension for the plan of work for exploration, or decides to renounce its rights in the area covered by the plan of work for exploration. 


\section{Specific national legislation Specific national legislation enacted before UNCLOS enacted after UNCLOS}

1. France

(Law on the

Exploration and

Exploitation of Mineral

Resources of the Deep

Seabed 1981;

In addition, France

incorporated an article

in an ordinance relat-

ing more generally to

all maritime spaces

under its sovereignty or jurisdiction. ${ }^{22}$ )

2. Japan

(Act on Interim Measures for Deep Seabed Mining 1982) ${ }^{23}$

3. the United States

(Deep Seabed Hard

Mineral Resources Act 1980) 1994), Regulations 2015), Jurisdiction 2000), the Sea Act 1996),
1. Australia (The Commonwealth Offshore Minerals Act

2. Belgium (Act on prospecting and exploration for, and exploitation of, resources of the seabed and ocean floor and subsoil thereof, beyond the limits of national jurisdiction, adopted on 17 August 2013),

3. Cook Islands (Seabed Minerals Act 2009, Amended in 2015; Seabed Minerals (Prospecting an Exploration)

4. Czech Republic (Act No. 158/200o of 18 May 2000 on Prospecting, Exploration for and Exploitation of Mineral Resources from the Seabed beyond Limits of National

5. Fiji (International Seabed Mineral Management Decree (Decree No. 21, 12 July 2013),

6. Germany (Seabed Mining Act of 6 June 1995 (the Act), Amended by article 74 of the Act of 8 December 2010),

7. Nauru (International Seabed Minerals Act 2015),

8. New Zealand (United Nations Convention on the Law of

\section{The Russian Federation}

(Decree of the President of 22 November 1994 No. 2099 "About activities of the Russian physical and legal entities for exploration and development of mineral resources of the seabed outside the continental shelf";

10. Singapore (Deep Seabed Mining Act 2015),

11. Tonga (Seabed Minerals Act 2014),

12. Tuvalu (Seabed Minerals Act 2014),

13. the United Kingdom (Deep Sea Mining (Temporary Provisions) Act 1981, amended by the Deep Sea Mining Act 2014).

22 Ordinance No. 2016-1687 of 8 December 2016 relating to the maritime areas under the sovereign-ty or jurisdiction of the Republic of France.

23 The Act provides for the regulations of mining activities by Japanese person in the Area. The Act is implemented by the Ordinance for Enforcement, which was enacted also in 1982 and last amended in 2013. 
China's first exploration contract signed in 2001 was due to expire in 2016. Thus, if the commercial development conditions are ripe, the contract may need to be transferred to the development stage. However, the current domestic laws, such as the "Mineral Resources Law", as mentioned above, were not sufficient for this purpose. Not only did the application scope of domestic laws not cover international seabed areas beyond the limits of national jurisdiction, but the legal language was also incompetent to govern increasingly active and complex activities conducted in the Area, which now involve huge investments, a long contractual period and high risks. Therefore, China's Deep Seabed Law was a necessary measure to follow up on current activities conducted in the Area.

The Deep Seabed Law has a total of 29 articles and divided into 7 chapters. ${ }^{24}$ Chapter I on General Provisions is the most extensive part of the law and comprised of 6 articles, which state the purposes and objectives, the scope of the application, as well as the general principles under which the mining activities should be conducted.

China's Deep Seabed Law was developed to serve five specific purposes: (a) regulating the exploration and development of resources in the Area; (b) promoting deep sea scientific and technological research and resource investigation; (c) protecting the marine environment; (d) promoting the sustainable utilization of resources in deep seabed areas; and (e) protecting the common interests of mankind. The law also states that the exploration and development of resources in deep seabed areas shall be conducted under the principles of peaceful utilisation, cooperation and sharing, environmental protection, and the protection of the common interests of mankind. Other countries such as the Czech Republic, Nauru, Tonga and Tuvalu have also recognised the principle of the "common heritage of mankind" in their respective national laws.

The law was adopted at the 19th Session of the Standing Committee of the Twelfth National People's Congress of the People's Republic of China on 26 February 2016 and came into force on 1 May 2016. Whereas Chapter VII addresses the terms and interpretation of the law, Chapters II through VI establish five primary mechanisms regulating different aspects of the mining activities in the Area:

Deep Seabed Law, supra note 1. 
1) a licensing procedure with a dual-track approval mechanism for exploration and development activities;

2) a marine environmental protection mechanism;

3) a sharing and cooperation mechanism for scientific and technological research and resource investigation;

4) a supervision and administration mechanism; and

5) a legal liability mechanism.

\subsection{Scope of Application}

The scope of the application contains three general aspects: eligible subjects; applicable activities; and applicable area.

\subsubsection{Eligible Subjects}

Pursuant to Article 2, the eligible subjects of the law apply to Chinese citizens, legal persons or organisations of the People's Republic of China. Article 153, paragraph 2 (b) of UNCLOS requires all persons interested in carrying out activities in the Area - whether natural or juridical - to possess the nationality of States Parties or be under the effective control of them or their nationals. Therefore, China and other countries such as Belgium, the Czech Republic, Fiji, Japan, Nauru, New Zealand, Singapore, Tonga and Tuvalu have all adopted this criterion of nationality or registration/residence within the domestic jurisdiction as a necessary requirement to be entitled to apply for State sponsorship.

Second, thus far, COMrA and China Minmetals are the only two Contractors sponsored by the Chinese government. However, law here clearly suggests that the identity of a Contractor is not restricted to state-owned enterprises, and any Chinese individual or organisation that passes the qualification screening would be eligible. Essentially, the government is opening the door for private enterprises and individuals to participate in deep seabed exploration in the future, stating that the applicant can qualify if "the application is in the national interest and the applicant has funds, technologies, equipment and other capabilities and conditions." Thus, the qualification requirements of an applicant is rather low and wide-ranging under China's Deep Seabed Law. Some other countries such as Japan and Fiji have stipulated more stringent rules governing the identity and qualification of the applicant. For example, Japan has a requirement regarding criminal records and the applicant is not eligible to apply for State sponsorship within two years after serving a sentence for criminal offences.

\subsubsection{Applicable Activities}

In relation to the range of activities it governs, Article 2 states that the law shall apply to activities in relation to the exploration and development of resources, 
environmental protection, scientific and technological research, and resource investigation. China defines "resources investigation" as "the searching for resources in deep seabed areas, including estimates of the components, quantity, distribution and economic value of resources", which is arguably equivalent to prospecting activities. However, there is no explanation as to what constitutes "resources" in the Deep Seabed Law, although it is speculated that "resources" should be interpreted in a generic way but only refers to nonliving resources. The legal status of living resources, such as marine or genetic resources, is a complex issue that prompts an international legal response. Therefore, the Chinese legislators may be of the opinion that the law should be intentionally silent on the definition of "resources" and that the adoption of rules dedicated to living resources should first be discussed at the international level.

When compared with the other 16 countries which have passed domestic laws relating to deep seabed mining ahead of China, China's Deep Seabed Law offers the broadest range of applicable activities, including environmental protection. ${ }^{25}$ The laws of Germany, the Czech Republic, and Belgium regulate prospecting, exploration, and development activities, while the laws of the United Kingdom and Japan primarily regulate exploration and development activities. Other countries such as the United States and Fiji focus more on the exploitation/development phase than the exploration/prospecting phase, without establishing any requirements for prospecting in their laws.

\subsubsection{Applicable Area}

Whereas the scope of the subject in other Chinese national laws concerning marine activities is generally connected to "territories", or governs activities in accordance with where they take place, the Deep Seabed Law, on the other hand, revolves around "one's activities", i.e., what the eligible subject actually does. Thus, it regulates the behaviour of the entity undertaking exploration and development activities within the Area. Moreover, it is the first extraterritorial law passed in China's legal history that governs activities outside its territorial waters.

With respect to the applicable area, the term "deep seabed area" is used in the law, instead of the term "the Area" as used in UNCLOS. For the purpose of the Deep Seabed Law, "deep seabed areas" means seabed, ocean floor, and the subsoil outside the jurisdiction of the People's Republic of China and other

25 Arguably the applicable activities do not include prospecting activities, although the definition given to "resource investigation" almost covers all prospecting activities. 
countries, which is exactly the same definition of "the Area" as defined by UNCLOS. ${ }^{26}$

\subsection{Competent National Authority}

Article 5 of the Deep Seabed Law establishes China's competent national authority for mining activities in the Area by stating, "the oceanic administration of the State Council is responsible for the supervision and administration of the exploration, development, and investigation of resources in deep seabed areas. Other relevant departments of the State Council shall be responsible for the relevant administration, according to the functions prescribed by the State Council".

Although not explicitly provided for, the "oceanic administration of the State Council" at large refers to China's State Oceanic Administration (SOA). However, it should be noted that the functions and responsibilities of the soA have now been divided and separated into two different, newly established ministries. Pursuant to the "Institutional Reform Plan of the State Council" which was approved at the first session of the 13th National People's Congress in March 2018, oceanic administration functions of the SOA now falls under the regime of the new Ministry of Natural Resources. Meanwhile, the marine environmental protection responsibilities of the SOA are now integrated into the regime of the new Ministry of Ecology and Environment. Although for convenience reason the Ministry of Natural Resources still retains the brand of State Oceanic Administration for the public, the SOA is now officially an office/a subordinate department within the Ministry of Natural Resources. The SOA/Ministry of Natural Resources functions as the inspection and regulatory body of the Deep Seabed Law and is responsible for the supervision and administration of activities conducted by Chinese nationals in relation to the exploration, development, and investigation of resources in deep seabed areas. the Ministry of Ecology and Environment is involved with respect to marine environmental protection issues. However, in practice, COMRA has a direct operational role in the implementation of the Deep Seabed Law as well as general oceanic administration affairs. For example, at the media conference for the promulgation of first implementing regulation of the Deep Seabed Law, it was the Secretary-General of COMRA, Mr. Liu Feng, rather than any government officials from the SOA to address the public in relation to the regulation.

Ideally, the institutional structure of governance should include the following: a legislative body, an executive branch, a regulatory and monitoring agency, as well as an oversight or appeal committee for agency decision-making. The 
National People's Congress is the legislative body. The soA plays the role of regulatory and monitoring agency but without a supervision entity for its decision-making. COMRA is both the regulatory and monitoring agency and a sponsored contractor. Responsibilities of the SOA and the COMRA are not defined, while COMRA is both an athlete and a referee. Arguably, procedural fairness cannot be guaranteed and this institutional arrangement should be improved in the future.

\subsection{Procedural Mechanism for Licensing}

Except for France and the Russian Federation, 14 out of the 16 countries which have enacted national laws to incorporate UNCLOS have established a procedural mechanism to control and grant a license or State sponsorship for mining activities in the Area. All of them grant a license/certificate of sponsorship based on the application.

Their respective regulatory approach can be roughly grouped into four types: ${ }^{27}$

a) A certificate of sponsorship without reference to a license/approval/ permit (the Czech Republic, Fiji and Nauru)

The national law provides that a certificate of sponsorship is to be entered into by the sponsoring State and the sponsored applicant. Obtaining State sponsorship is a pre-condition for a contract application to the ISA. The Czech Republic requires an applicant to get a certificate of sponsorship before negotiations with the Authority; however, there is no reference to a licensing mechanism in the law. This approach is followed by countries such as Fiji, Nauru, and the Czech Republic.

b) A license (approval or permit) for seabed mining activities within national jurisdiction and a certificate of sponsorship for activities in the Area (Tonga and Tuvalu)

Both the States' sponsorship scheme and the licensing procedure are provided in detail via the domestic laws, such as can be seen in Tonga and Tuvalu.

27 Wang Lan (王岗), Guoji Haidi Quyu Kaifa Zhongde Guojia Danbao Zhiadu Yanjiu (国际海 底区域开发中的国家担保制度研究 - 中国国家担保制度立法回应) [Research on the National Guarantee System for International Seabed Area Development], 223 Xue Shu Jie (学术界) [Academics] 209 (2016); and ISA, Comparative Study of the Existing National Legislation on Deep Seabed Mining (2017), [hereinafter ISA comparative study]. 
c) A certificate of sponsorship is to be issued after a license has been granted (Singapore)

Singapore's State sponsorship scheme is only lightly touched upon in the Deep Seabed Mining Act 2015, with great emphasis attached to the licensing procedure. Thus, Singapore fulfils its sponsoring State obligations mainly through the licensing mechanism.

d) A license (approval or permit) without explicit reference to the certificate of sponsorship (Germany, Japan and the United Kingdom), but in practice, a certificate of sponsorship is issued for sponsored contractors.

No direct State sponsorship scheme is addressed in the domestic law; however, the sponsoring State commitment is integrated into the licensing system under the specific Deep Seabed Law. Such an approach is found in Germany and the UK.

China adopts the last approach. A licensing scheme is detailed in the Deep Seabed Law without explicit reference to the certificate of sponsorship. In accordance with Articles 7 and 8, before any Chinese citizen, legal person or organisation can apply to the ISA for an exploration and development contract, the entity shall first file an application with the SOA. The SOA will then examine the application materials submitted and conduct a qualification review. If successful, the SOA will grant a permit to the applicant within 60 working days. After obtaining the permit, the entity is then eligible to enter into an exploration and development contract with the ISA and become a Contractor. A duplicate copy of the ISA contract must be submitted to the soA for record purposes no more than 30 days from the date of the signature.

In essence, China's Deep Seabed Law has established a dual-track approval mechanism for exploration and development activities in the Area, namely, a valid license (approval or permit) issued by the SOA under domestic law, and a valid contract signed with the Authority under international law, prior to the applicant commencing activities in the Area. A similar practice can be seen in other countries such as the Czech Republic, Fiji, Germany, Japan, Nauru, New Zealand, Singapore, Tonga, Tuvalu, and the United Kingdom, which similarly provides a general prohibition on deep seabed mining activities in the Area unless the applicant holds a valid national license/State sponsorship. China further requires a valid contract with the Authority for activities in the Area.

This dual-track (national and international) approval procedure means that sponsored contractors are bound by Chinese domestic laws, as well as contractual terms with the ISA. The former domestic procedure is the prerequisite for the latter. The SOA validates and approves the qualification of the applicant and provides its consent for the applicant to enter into contracts with the ISA. 
Details of the contractual terms still depend on the negotiations between the contractor and the ISA. If a contract is not successfully concluded with the ISA within 3 years after the grant of the license, the license automatically expires. ${ }^{28}$ In addition, the effective period of the license spans from the date of grant to the expiry date of the ISA contract. ${ }^{29}$ If the ISA contract requires an extension, before the contractor files an extension application to the ISA, the contractor should first apply for an extension of the license with the SOA. The SOA has 60 working days to make a decision whether or not to allow the extension of the license and each extension period is no more than 5 years. ${ }^{30}$ Essentially, the soA could unilaterally withdraw State sponsorship and terminate the ISA contract if it refuses to extend the license. This type of governance system is new to Chinese authorities, which requires the SOA to fully consider the relevant international rules, while understanding the limits of their functions and powers. In that respect, the interaction between international laws and the provisions of the Deep Seabed Law affecting the rights and duties of the contractors may stress some areas of conflict and, thus, represent a challenge for Chinese judicial authorities in the future. The implementation impact of this practice is yet to be seen.

\subsubsection{Application Documentation}

With respect to the application documentation, Article 7 of the Deep Seabed Law provides that an application with the soA must be in writing, and should include the following:

a) Basic information about the applicant, such as nationality, residency, and company registration information;

b) An explanation regarding the location and area of the region that the applicant intends to explore and develop, and the categories of minerals;

c) Certificates of financial status and investment ability, and an explanation concerning technical capability;

d) An exploration and development work plan, including the materials relating to the possible impact of exploration and development activities on the marine environment, and an emergency response plan for serious damage to the marine environment, among others; and

e) Other materials required by the oceanic administration of the State Council.

$28 \quad 2017$ Implementing Regulation on Licensing, Infra note 30, Art.11.

29 Id.

30 2017 Implementing Regulation on Licensing, Infra note 30, Art.15. 
Whereas "materials on the possible impact of exploration and development activities on the marine environment" is vaguely mentioned in the Deep Seabed Law, the implementing regulation on licensing issued by the SOA in 2017 specifically requires an environmental impact assessment to be produced and an establishment of environmental baseline data. ${ }^{31}$

\subsubsection{Criteria for Granting a License}

In China, a number of eligibility criteria are required prior to the SOA granting the license: the application must be in the national or public interest; and the applicant must have sufficient funds and possess competent technical and technological capabilities. Although not manifested in the Deep Seabed Law, the implementing regulation on licensing further requires an assessment of the credibility and integrity of the applicant, and that the applicant is equally satisfying the eligibility criteria established by the ISA regarding the exploration and development of marine resources. ${ }^{32}$

\subsubsection{Scope of the License}

China's Deep Seabed Law foresees the scope of a national license covering two stages of deep-sea mining activities, namely exploration and development. Article 27 of the Deep Seabed Law defines "Exploration" as "the searching and analysis of resources in deep seabed areas, use and testing of resource collection systems and equipment, processing facilities and transport systems, as well as the research on environment, technologies, economy, commerce and other relevant factors that shall be considered at the time of development." Moreover, "Development" is defined as "the recovery and selection of resources in deep seabed areas for business purposes, including the construction and operation of collection, processing and transport systems serving the production and sale of resources."

Other countries such as Japan, New Zealand, Singapore, Tonga, Tuvalu and the United Kingdom may grant two types of licenses/certificates regarding exploration and exploitation, respectively. ${ }^{33}$ For example, Singapore's license must specify whether they are for exploration or exploitation, the type of

31 Shenhai Haidi Quyu Ziyuan Kantan Kaifa Xuke Guanli Banfa (深海海底区域资源 勘探开发许可管理办法) [Measures for the Management of Permits on Exploration for and Exploitation of Resources in the Deep Seabed Area] (promulgated by the State Oceanic Administration, Apr. 27, 2017, effective Apr. 27, 2017) Art.6(6) [hereinafter 2017 Implementing regulation on licensing], http://www.gov.cn/gongbao/content/2017/con tent_5227831.htm.

32 Id. Art.8.

33 Permits for exploration activities and mining activities in the case of Japan. 
resource, and the part of the Area and the license must relate to only one type of resource. ${ }^{34}$ In the Cook Islands, four types of certificates are issued: a prospecting permit, an exploration license, a mining license, and a retention lease. ${ }^{35}$

\subsubsection{Transfer, Variation, Revocation, Termination of License/Certificate of Sponsorship/the ISA Contracts}

The Deep Seabed Law allows a contractor to transfer, modify, and terminate the ISA contract as long as it informs the soA for approval. The contractor shall, within 30 days of the transfer, modification or termination of the exploration and development contract, report the issue to the soA for recordation. ${ }^{36}$ A major modification to the license is allowed, but is governed by the implementing regulation on licensing instead. Under the circumstances of a major modification to the exploration and development work plan, a major modification or revision of the ISA contract, or a transfer (all or partly) of the obligations under the ISA contract, a modification or reissuance of the license may be approved. However, whereas ISA contracts can be transferred under the Deep Seabed Law, the implementing regulation is not clear with respect to whether a license could be transferred equally. As a comparison, in its 2010 Seabed Exploration Act, Germany does not allow a contractor to transfer its rights and obligation under an approval (license).

Moreover, many States have provided in their national law for the competent national authority to vary, suspend or revoke the license/certificate of sponsorship in certain cases. For example, the corresponding contract with the Authority has been suspended for any reason or it is in the national interest to suspend or revoke the license (Singapore), and to avoid a conflict with any obligation of the sponsoring State arising out of any international agreement or instrument in force (Nauru, Tonga and the United Kingdom).

Although not provided in the Deep Seabed Law, the 2017 implementing regulation on licensing has established situations under which the soA may revoke or terminate the license if the licensed:

a) Provided false or misleading information to obtain the license (Article 23(1));

34 ISA comparative study, supra note 27 , at para.40.

35 Zhang Zitai \& Sheng Hao (张梓太\&沈影), 深海海底区域资源勘探开发立法研究 域外经验与中国策略 [Research on Laws Governing Exploration and Development of Deep Seabed Resources - Foreign Experience and China' Strategy] conference paper in National Symposium on Environmental and Resource Law, edited by Chinese Society of Environmental and Resource Law, 700, Guangzhou, 2014.

Deep Seabed Law, Supra note 22, Art.10. 
b) Failed to perform the ISA's contractual obligations or perform obligations in any manner other than complying with the terms of the contract (Article 23(2));

c) Has transferred or significantly modified the rights and obligations under the ISA contract without the SOA's approval (Article 23(3));

d) Does not apply for an extension upon expiry of the license (Article 24(1));

e) No longer meets the qualification criteria for the exploration and development of deep seabed marine resources (Article 24(2));

f) Upon the bankruptcy, insolvency or receivership of, or ceasing to exist as a legal entity of, the sponsored party (Articles 24(3) and 24(4)); and

g) Under other situations where the license is lawfully terminated (Articles 24(5) and 24(6)).

\subsection{Rights, Obligations and Liabilities of a Sponsored Contractor}

The rights, obligations and responsibilities of the licensee/sponsored contractor are directly set out in Articles 9-11 of China's Deep Seabed Law. Some other countries such as Singapore and the United Kingdom provide for rights and obligations of the licensee under the terms and conditions of the license, which may have the inconvenience of having a lower legislative ranking and which may have less constraint on the contractors.

With respect to rights, Article 9 of the Deep Seabed Law affirms that a contractor has the exclusive rights to explore and develop specific resources within the region specified in the exploration and development contract. "Resources" here was not defined in the legislation. However, as the Deep Seabed Law directly incorporates the UNCLOS, it can be inferred from Article 133 of the UNCLOS that "resources" means all solid, liquid or gaseous mineral resources in situ in the Area at or beneath the seabed. ${ }^{37}$

With respect to obligations of the sponsored contractor, they amount to a comprehensive list in the Deep Seabed Law and may be classified into the following categories:

a) to perform obligations under the exploration and development contract;

b) to guarantee the personal safety of employed operation persons subject to Chinese laws and the administrative regulations on work safety and labour protection;

c) to ensure the safety of the vessels, installation, equipment and operations in the Area;

d) to protect the marine environment, among others, including taking necessary measures to protect and preserve rare or fragile ecological systems 
and the living environment of weakened, threatened or endangered species and other marine organisms;

e) to safeguard the objects of archaeological and historical nature in the Area;

f) to periodically update the Authority and the SOA on the performance of exploration and development contracts; and

g) to assist and cooperate in the supervision and inspection conducted by the SOA.

On the other hand, countries such as Fiji, Tonga and Tuvalu have provided in their national laws a number of responsibilities of the sponsoring State for the benefits of the sponsored contractor. These responsibilities, among others, include communicating and providing any assistance to the Authority to give effect to the State's sponsorship and not imposing unnecessary and disproportionate regulatory burdens on sponsored parties. China however limits its role and responsibilities of sponsoring States only to review and approve the transfer of license/ISA contracts and keep corresponding records. Even though Article 3 of the Deep Seabed Law unequivocally states that the State shall protect the lawful rights and interests of Chinese citizens, legal persons or other organisations that conduct the exploration, development and investigation of resources in the Area, the effectiveness of that is doubtful.

\subsubsection{Supervision and Inspection}

Like the Czech Republic, Fiji, Germany, Japan, Nauru, Singapore, Tonga, Tuvalu and the United Kingdom, China has established a monitoring, supervision and inspection mechanism by the competent national authority in Chapter v of the Deep Seabed Law.

The measures include sending an inspector and obtaining access to the contractor's vessels, facilities and equipment; examining relevant documentation, including logbooks, records and data; requiring the contractor to report regularly on the implementation of the exploration and development contract; and ensuring the contractor provides assistance and cooperate with the inspection team.

\subsubsection{Legal Liabilities}

Except for France and Russia, all countries which have domestic laws in place for mining activities in the Area have explicitly stipulate sanctions in case of a breach of contractors' obligations. Chapter VI of China's Deep Seabed Law defines a sanction regime in the form of contractors' legal liabilities in case of non-compliance. In most cases, a non-compliance situation will result in fines, orders to take corrective actions or the revocation of the license by the soA. The contractor may be exposed to criminal liabilities only for acts which 
cause pollution or damage to the marine environment or to the cultural relics and paving things within the operation area. If any crime is constituted, it shall be subject to criminal liability in accordance with the law. ${ }^{38}$ This again has demonstrated China's firm commitment to marine environmental protection.

Other countries have also established financial penalty mechanisms in their respective national laws. The amounts of the fines depend on the type of offence, but the severity of the sanctions in relation to offences varies from one country to another. The Czech Republic, for instance, sanctions the acts of undertaking seabed mining activities without State sponsorship or without a contract for over 4 million USD, while Tonga's fines for an equivalent offence can be up to 1 million USD. In comparison, China imposes a fine of not less than 500,000 yuan but not more than 1 million yuan (around 148,000 USD) for even its most serious type of offence. China can also confiscate, in addition to the fines, the gains and products derived from the illegal mining activities. It is speculated that China's sponsored contractors often have close ties to the central government or directly under the control of the government; hence, a low penalty scheme is sufficient to serve as deterrence for non-compliance. With the increasing cohort of private entities sponsored by States Parties, China's penalty mechanism might be revised in the future.

\subsection{Environmental Protection Mechanism}

Unlike the sponsorship requirement which only the State Parties willing to cooperate with the ISA will implement into domestic laws, the protection of the marine environment with respect to deep seabed mining activities has received global consensus. Many countries, including the United States which currently is an observer to the ISA and a non-party to the UNCLOS, have adopted a compensation and penalty mechanism for pollution and damage to marine environments. Some States set the element of marine environmental protection as one of criteria for granting a license/certificate of sponsorship (Nauru, Tonga, Tuvalu and the United Kingdom), while others set out in national laws the general or specific obligations of the licensee/contractor to protect the marine environment (Belgium, China, Czech Republic, Germany, Japan and the United Kingdom). ${ }^{39}$

China has prioritised marine environment protection and made it a full part of the country's marine strategy. This priority focus is reflected in the Deep Seabed Law, where the word "environment" is mentioned 20 times and the law dedicates a whole chapter (Chapter III) to environmental protection. As to

\footnotetext{
38 However, the law refers to the applicability of criminal law without specifying minimum or maximum imprisonment time. 
the content of the requirements, Chapter III provides that a contractor shall apply the available advanced technologies and take necessary measures as far as reasonably practical: (i) to investigate and conduct research on the oceanic conditions; (ii) to establish environmental baselines and assess the possible impacts of mining activities; and (iii) to make and implement an environmental monitoring plan in order to prevent, reduce and control pollution and other damage to the marine environment caused by activities in the exploration and development area.

The Deep Seabed Law also addresses emergency situations by providing an emergency response plan. If an accident causing serious damage to the marine environment occurs or may occur, the contractor shall immediately sound an alarm, report to the SOA, and initiate the emergency response plan in accordance with Article 11. Similarly, the Acts of Fiji, Nauru, Tonga and Tuvalu also contain contingency plans of "incident" reporting, response and inquiry processes. Such environmental contingency plans are triggered by situations of pollution or serious harm to the environment.

In addition, Chapter I on General Provisions and Chapter II on Exploration and Development contain supplementary provisions related to marine environmental protection:

a) Article 1 stipulates that one of the objectives of the law is to protect the marine environment;

b) Article 3 requires that the exploration and development of resources in deep seabed areas shall be conducted in accordance with the principles of, inter alia, environmental protection and protection of the common interests of mankind;

c) Article 4 requires the State to adopt economic and technical policies and measures to enhance the capability of the protection of the marine environment;

d) Article 6 states that the government should encourage and support international cooperation in relation to environmental protection, scientific and technological research, education and training, among others;

e) Article 7 requires that the exploration and development plan submitted to the SOA for permit application should include background materials on the possible impact of exploration and development activities on the marine environment, including an emergency response plan for serious damage to the marine environment; and

f) Article 9 provides that the contractor shall perform the exploration and development contract under the obligation, inter alia, to protect the marine environment.

Compared to the other 15 countries which have passed domestic laws to regulate the deep seabed mining activities, China has demonstrated a high degree 
of commitment, and probably it is the only country prioritising the issue of marine environmental protection in its domestic law.

Besides national requirements, the three ISA Regulations have set out six environmental protection measures. ${ }^{40}$ Some of them provide the basis for the national provisions mentioned above:

a) The contractor should "take necessary measures to prevent, reduce and control pollution and other hazards to the marine environment ... as far as reasonably possible using the best technology available to it ...", and "apply a precautionary approach, as reflected in Principle 15 of the Rio Declaration, and best environmental practices"; 41

b) The contractor should establish and implement programs for monitoring and evaluating the impacts of deep seabed mining on the marine environment; ${ }^{42}$

c) The contractor should gather environmental baseline data and establish environmental baselines; ${ }^{43}$

d) Prior to the commencement of its programme of activities, the contractor should submit a contingency plan to the Secretary-General to respond effectively to incidents that are likely to cause serious harm or constitute serious threats to the marine environment when performing contractor's activities; ${ }^{44}$

e) The contractor shall promptly report to the Secretary-General any incident arising from its activities that has caused, is causing or poses a threat of serious harm to the marine environment; ${ }^{45}$ and

f) The contractor should comply with emergency orders issued by the Council of the ISA, as well as the immediate measures issued by the Secretary-General, to prevent, contain, minimise or repair serious harm or the threat of serious harm to the marine environment. This may

40 Namely, the Regulations on Prospecting and Exploration for Polymetallic Nodules in the Area (adopted 13 July 200o, updated and adopted 25 July 2013) [hereinafter Polymetallic Nodules Regulations]; Regulations on Prospecting and Exploration for Polymetallic Sulphides in the Area (adopted 7 May 2010) [hereinafter Polymetallic Sulphides Regulations]; and the Regulations on Prospecting and Exploration for Cobalt-Rich Crusts (adopted 27 July 2012) [hereinafter Cobalt-rich Crusts Regulatons], https://www.isa.org .jm/mining-code.

41 For example, Polymetallic Sulphides Regulations, https://ran-s3.s3.amazonaws.com/isa .org.jm/s3fs-public/files/documents/isba-16a-12revı_o.pdf, similar provisions are also provided in other two regulations.

42 Id. Part 5, Regulation 33, para.6.

43 Id. Annex4, section 5.3.

$44 \quad I d$. Annex4, section 6.1.

$45 \quad$ Id. Annex 4, section 6.2. 
include orders to the contractor to immediately suspend or adjust any activities in the exploration area. ${ }^{46}$

Some States emphasise the application of the precautionary approach and best environmental practice (Fiji, Nauru, Tonga and Tuvalu), while others implicitly include these principles in the national laws by endorsing the Authority's rules, regulations and procedures. ${ }^{47}$ China has fully incorporated these measures into its Deep Seabed Law and sets out standards, which are no less stringent than the requirements of ISA Regulations. In addition, the preservation of the ecosystem, the protection of endangered marine species, the preservation of marine biodiversity, and the sustainable use of marine resources required under Article 14 of the law also embody the principles of the resolution adopted by the United Nations General Assembly at RIO+20 on 27 July 2012.48

Moreover, other Chinese laws and regulations have also provided a solid legal foundation for marine environmental protection. Domestic laws such as the "Marine Environmental Protection Law of the People's Republic of China" and the "Administrative Regulation on the Prevention and Treatment of the Pollution and Damage to the Marine Environment by Marine Engineering Construction Projects" address environmental pollution and ecological damage caused by the exploitation and use of marine resources. Nevertheless, these laws only govern activities taking place in areas within China's jurisdiction. The promulgation of the Deep Seabed Law further complements and strengthens the legal system for marine environmental protection in China.

However, although it is applauded that China's Deep Seabed Law emphasises the ultimate importance of marine environment protection, relevant provisions in the law are quite vague and general. For instance, specific rules regulating environment impact assessment are still found wanting. Supplementary laws and administrative regulations shall be rolled out in the future to provide details and clarification. According to news report, the soA previously had plan for four implementing regulations to be issued in 2017. The first three have already been promulgated in April 2017, December 2017, with the last "Measures for the Environmental Investigation and Assessment of Resources in Deep Seabed Areas" still in the pipeline.

\footnotetext{
$46 \quad I d$. Annex 4, section 6.3.

47 ISA comparative study, supra note 27 , para.58.

48 The Future We Want, unga Res. 66/288, para. 158, U.N. Doc. A/RES/66/288 (Sept. 11, 2012), http://www.un.org/ga/search/view_doc.asp?symbol=A/RES/66/288\&Lang=E.
} 


\subsection{Information Sharing and Cooperation}

Few countries have stressed the importance of the sharing and cooperation mechanism contained in their respective national laws. As a general rule, Belgium, Fiji, Nauru, Tonga, Tuvalu and the United Kingdom regard data and information received as confidential or to be held with appropriate confidentiality, with only a few prescribed exceptions specified under their laws. ${ }^{49}$ China, on the other hand, requires the soA to register and retain the information and samples submitted by the persons or entities that conduct deep sea mining activities, and make such information and samples available for public use pursuant to relative rules. In fact, China takes this step further by stipulating in the Deep Seabed Law that it supports the construction and operation of a "deep sea public platform" for the purpose of sharing the benefits arising from its research as related to deep sea technology and the exploration for deep sea resources. Again, this tends to further demonstrate China's commitment to the peaceful and sustainable utilization of deep-sea resources for the benefit of all mankind.

At its core, China's Deep Seabed Law is about controlling, securing and preparing, as will be elaborated below.

First, the main theme of the law is to regulate and pursue an effective control mechanism for the activities in the Area. The very first sentence of Article 1 has stipulated that this law, among others, is developed for the purpose of regulating the exploration and development of resources in deep seabed areas. This stipulation fully reflects the law's basic value judgement as a tool to command and control. Chapter II then dedicates a whole chapter on exploration and development regulation, and it includes a licensing mechanism, eligibility criteria for applicants, comprehensive obligations for sponsored contractors and stringent restriction on modification and transfer of the contracts. Chapter III also dedicates a whole chapter on regulating exploration and development activities; however, it does this via a different angle of imposing marine environment protection obligations. To reinforce the control mechanism, Chapter v grants the soA supervision and inspection rights with respect of mining activities conducted in the Area, and it is an obligation for contractors to assist and cooperate with the inspection team. Moreover, 
the non-compliance of a contractor's obligations under the law attracts a financial penalty or even criminal imprisonment as detailed in Chapter vi. In summary, the law is devised more for the benefit of the government to carry out the State's "responsibility to ensure". Therefore, it is understandable that the reciprocal obligations of sponsoring States are not emphasised.

Second, the law is to secure and protect the lawful rights and interests of citizens, legal persons or other organizations of the People's Republic of China that conduct mining activities in the Area, as enshrined in Article 3 of the law. Since its launch in 1994, the ISA has issued twenty-nine (29) 15-year contracts for the exploration of deep sea minerals, with China holding four of them. In the future, China is expected to continue more intensive engagement and cooperation with the ISA. The provisions of the Deep Seabed Law are largely rooted in the provisions of the UNCLOS and ISA Regulations, which demonstrates China's support for the international legal regime of the Area, thus consolidating ISA's function further. China's promulgation of the Deep Seabed Law contributes to its own discourse power and discourse rights within the Council of ISA; hence this measure ensures effective protection of Chinese citizens' rights in the Area. However, it is arguable whether the law per se could effectively protect rights of sponsored contractors with only one Article (Article 9) stipulating vaguely and generally that "a contractor shall enjoy corresponding exclusive rights to explore and develop specific resources within the region specified in the exploration and development contract". 50 Moreover, the responsibilities of China as a sponsoring State were only restricted to review and approve the transfer of license/ISA contracts and keep corresponding records. The law also lacks provisions regarding the rights of relief and the rights of appeal if a contractor's rights are infringed by the sponsoring State under the law. Given the legal uncertainty, further implementing regulations or judicial interpretations relevant to securing contractors' rights should be supplemented to the Deep Seabed Law.

Third, to prepare China for greater capability in relation to deep seabed mining activities in the Area, with reference to Articles 15-17, a number of incentive measures have been put in place to advance China's deep-sea scientific and technological research and to facilitate China's capacity-building for mining activities in the Area. Encompassing these measures, Chapter IV of the Deep Seabed Law dedicates a whole chapter on "Scientific and Technological Research and Resource Investigation".51

5o Deep Seabed Law, supra note 1, Art.9.

51 'Resource investigation' is defined under the Deep Seabed Law as the search for resources in deep seabed areas, including the estimates of the components, quantity, distribution 
a) The State supports the training of professional talents and encourages research cooperation between relevant industries;

b) The State lists deep-sea science and technology among the priority fields of scientific and technological development, meaning that more government spending would be devoted to this Area;

c) The State encourages private enterprises to carry out deep-sea scientific research and marine technology equipment research, essentially opening doors for a diversity of participants;

d) The State supports the construction and operation of a "deep-sea public platform", which is a mechanism to promote information exchange, cooperation and result sharing;

e) The State encourages entities and individuals to conduct deep-sea science popularization activities such as opening vessels for exhibitions, holding seminars and providing relevant consultation services; and

f) The State shares with the public the physical samples and relevant materials obtained by contractors from investigation, exploration and development activities in accordance with relevant provisions.

China is the only country that promotes resources investigation and marine scientific research as one of its legislative objectives under the law. Chinese legislators are of the opinion that capacity-building is the foundation of the preceding two objectives mentioned previously. A State does not even possess the competent ability to conduct deep sea mining activities let alone to effectively regulate its sponsored contractors and to protect their legal rights and interests. Competent ability relates to the technology, the equipment and the qualified personnel. By stipulating such content of national policy/strategy in its national law on deep seabed mining, China is preparing itself to move onto the next stage of commercialization of deep seabed resources once the conditions are matured.

\section{Significance of the Law}

With the enactment of China's Deep Seabed Law in 2016, it is worth assessing its significance and the influence it may have on the international regulations governing deep seabed resources. Three main points can be made.

and economic value of resources. Arguably, it is similar to the definition of prospecting under the Mining Code. 


\subsection{A Regulatory Blueprint for Other National Legislation}

First, the law could be viewed as an effective precedent for countries who are yet to pass domestic legislation governing international seabed activities.

The Deep Seabed Law, in many ways, is a direct incorporation of the contents and requirements of the relevant international rules. Many provisions under the Deep Seabed Law are resonant with the legal wording formulated under the UNCLOS and other supplementary legal instruments (together referred as the "Mining Code"). ${ }^{52}$ For example, the definition of "deep seabed areas" established under the Deep Seabed Law has similar wording as the "Area" as defined under UNCLOS Article 1.

On the other hand, the law contains some additional requirements that are not covered by the Mining Code, such as the protection of marine biodiversity and relevant financial arrangements with respect to the development of resources in deep seabed areas. The Deep Seabed Law also emphasises the importance of international cooperation as well as the peaceful exploitation and certain human rights protection issues, which mirrors the principles established in the Rio+2o UN Resolutions and the Mining Code.

Moreover, words and terms are carefully crafted in China's Deep Seabed Law and many represent legal innovations from Chinese legislators. For example, unlike other definitions, the Deep Seabed Law does not directly transplant the term "common heritage of mankind" as prescribed in Article 136 of the UNCLOS, but rather has adopted the term "common interests of mankind" derived from the term or concept of "benefit of mankind as a whole" as prescribed in Articles 140(1), 143(1), 149 and 150(i) of the Convention. Article 136, Part XI of the UNCLOS stipulates "the Area and its resources are the common heritage of mankind", whereas Article 140(1) and 150(i) of the UNCLOS state that "Activities in the Area shall ... be carried out for the benefit of mankind as a whole". It, therefore, signifies that the term "common heritage of mankind" is closely linked with "the Area and its resources", while the concept of "benefit of mankind as a whole" governs "activities" in the Area. As Article 2 of the Deep Seabed Law provides that the law shall apply to "activities" conducted by Chinese entities in the Area, it is more appropriate to use the term of "common interests" rather than "common heritage", while not frustrating

$5^{2}$ The "Mining Code" refers to the whole of the comprehensive set of rules, regulations and procedures issued by the International Seabed Authority to regulate prospecting, exploration and exploitation of marine minerals in the international seabed Area (defined as the seabed and subsoil beyond the limits of national jurisdiction). At its core, it includes the UNCLOS, the Implementation Agreement and the three ISA Regulations, among others. See Chapter 7 of this book, J. Dingwall, 'Commercial Mining Activities in the Deep Seabed Beyond National Jurisdiction: The International Legal Framework’. 
the well-established international legal status of "the Area and its resources". However, although "common heritage of mankind" is not specifically articulated in the Deep Seabed Law, the principle of "protection of the common interests of mankind" does not deviate from the common heritage principle under the UNCLOS and is precisely in-line with the Convention. At the same time, it allows more flexibility in applying the Chinese law to more Area activities in the future, such as the sharing and cooperation mechanism of the undefined "deep seabed public platform".53

Another example is the definitions of "exploration" and "exploitation" ("development" as in the Deep Seabed Law). China's Deep Seabed Law largely directly incorporates the two definitions given under the ISA Regulations. The only nuanced difference between the two is that the latter has specifically designated the resources as the three kinds of minerals in the Area, ${ }^{54}$ whereas China's Deep Seabed Law uses a more generic meaning of "resources".55 The intentionally undefined term "resources" has thus left room for further interpretation and clarification, which also provides the law with some flexibility for application.

In summary, this law has enshrined the fundamental spirit of international laws in relation to the exploration and exploitation activities in the Area, and at the same time preserved a flexibility to cater to national circumstances. In view of the growing interest in the development of marine minerals in the

53 G. Zhang \& P. Zheng, A new step forward: Review of China's 2016 legislation on international seabed area exploration and exploitation, 73 Marine Policy 251 (2016).

54 Supra note 40. For the purposes of these Regulations: (a) "exploitation" means the recovery for commercial purposes of polymetallic nodules, polymetallic sulphides and cobalt-rich ferromanganese crusts in the Area and the extraction of minerals therefrom, including the construction and operation of mining, processing and transportation systems, for the production and marketing of metals; (b) "exploration" means searching for deposits of polymetallic nodules, polymetallic sulphides and cobalt-rich ferromanganese crusts in the Area with exclusive rights, the analysis of such deposits, the testing of collecting systems and equipment, processing facilities and transportation systems, and the carrying out of studies of the environmental, technical, economic, commercial and other appropriate factors that must be taken into account in exploitation.

55 Deep Seabed Law, supra note 1, Article 27(1) and (2): "Development" means the recovery and selection of resources in deep seabed areas for business purposes, including the construction and operation of collection, processing and transport systems serving the production and sale of resources. "Exploration" means the searching and analysis of resources in deep seabed areas, use and testing of resource collection systems and equipment, processing facilities and transport systems, as well as the research on environment, technologies, economy, commerce and other relevant factors that shall be considered at the time of development. It should be noted that the English translation of China's Deep Seabed Law may not be accurate and therefore may not be the exactly same wording as the ISA Regulations definitions. 
deep seabed, both within the limits of a national jurisdiction and in the Area, China's Deep Seabed Law could serve as an appropriate reference for the follow-up legislative work of other States Parties.

\subsection{A Contribution to the Development of International Rules}

Second, the law facilitates the legislative work at an international level. The international community is increasingly discussing matters related to the Area, and with a particular focus related to the establishment of supplementary legal rules to UNCLOS. As the $5^{\text {th }}$ pioneer investor of the ISA, China is a major participant in all ISA meetings and is an important opinion leader for the ISA Assembly resolutions. In the past, Chinese delegates have proposed numerous insightful and productive opinions which have helped to shape the overall legal regime of the international law of the sea. It was a major shortcoming that China previously lacked a domestic legislation in relation to deep seabed issues. Therefore, the introduction of the Deep Seabed Law has had immeasurable and far-reaching significance to strengthen China's discourse in vying for the influence on other countries.

In addition, with its first set of 15 -year exploration contracts ending in 2016-2017, there is an urgent need for the IsA to make progress on the development of an appropriate fiscal and legal regime that would allow those contractors, including Chinese contractors, to proceed toward commercial development, while at the same time safeguarding the interests of the members of the Authority as a whole. China's domestic Deep Seabed Law includes not only the content governing exploration activities, but also establishes the rules relating to developmental activities. These provisions could essentially provide further references for the ISA, and contribute to the relevant rule-making relating to the commercial recovery of mineral resources from the Area.

\subsection{Regulating a Sphere of Intense Competition between States}

Third, the law evidenced China as a rule-abiding international community member. Most notably, China is now in a position to mediate various conflicting interests between industrialized states and developing countries for the exploration and development of deep seabed resources. China is not the first country with high ambitions in the Area and the deep seabed in general. Since the 196os, industrialized states such as the United States, the United Kingdom, Germany, Japan and Russia have been conducting regular deepsea surveys of marine resources. By the early 1980s, the Pacific Ocean deep seabed area, which had the most commercial potential consisting of nearly 2.8 million square kilometres, had almost been divided among these countries who regard their active presence as a legitimate exercise of high seas freedom. 
In order to challenge excessive maritime claims, the UNCLOS and the 1994 Implementation Agreement have since been ratified by 168 states.

As a developing country, China was granted the largest number of exploration contracts by the ISA. On the other hand, China's marine technology is rapidly improving and fast approaching the technological level of developed countries. Nevertheless, with China's rising international influence and its increasing activities in the Area in recent years, it has attracted some criticism voiced as the "deep-sea threat from China". For example, when comra signed the second exploration contract with the ISA in 2011, other developing countries such as India reacted with fierce criticism. Thus, there might be some elements of competition between States with respect to these reactions. The Deep Seabed Law, especially Article 16, has, therefore, addressed the conflict by stating that China supports the construction and operation of a "deep sea public platform" for the purpose of sharing the benefits and knowledge generated from its research focusing on deep sea technology and the exploration of marine resources.

Meanwhile, there is always a fragile balance of interests to accommodate national ambitions to access deep seabed resources and common interests surrounding the exploitation and protection of those marine areas. By adopting the Deep Seabed Law, China pledges its commitment to the peaceful and sustainable utilisation of deep-sea resources with the associated goal of motivating more countries to ratify the UNCLOS agreement and cooperate with the ISA. Moreover, it reinforces China's stance that all activities in the Area shall be carried out for the benefit of mankind as a whole, while taking into particular consideration the interests and needs of developing States.

Although a relatively comprehensive and intricately crafted law, the Deep Seabed Law is not without its limitations.

The first limitation relates to the lack of an adequate definition for "prospecting". ${ }^{56}$ In other words, China's Deep Seabed Law does not distinguish the "prospecting" stage from the "exploration" stage, although prospecting is a

$5^{6}$ Arguable, the term "Resource investigation" used in the Deep Seabed Law equals to "Prospecting" but is not given the rights as tended to "Prospecting" under the ISA Regulations. "Prospecting" under the ISA Regulations refers to "the search for deposits of polymetallic nodules, polymetallic sulphides, cobalt-rich ferromanganese crusts in the Area, including estimation of the composition, sizes and distributions of deposits and their economic values, without any exclusive rights". "Resource investigation" is defined in Article 27(3) of China's Deep Seabed Law as "the searching of resources in deep seabed 
separate preparation stage of exploration and is entirely different from exploration in nature. Meanwhile, the legal importance of distinguishing prospecting from exploration is that the rights and obligations of "prospecting" under international laws are quite different from that of "exploration". Pursuant to the ISA Regulations, ${ }^{57}$ there are no regional and time restrictions on prospecting, and the prospector is not required to sign a contract with the ISA. ${ }^{58}$ Although no exclusive property rights are granted to the prospector, a prospector has the right to recover "a reasonable quantity of minerals", as long as the quantity is necessary for testing and is not collected for commercial use. China is actively engaged in prospecting activities in the Area; thus, the absence of rules prescribed to prospecting may lead to confusion and create legal uncertainty for Chinese contractors. Therefore, the formulation of relevant implementing regulations or judicial interpretations is essential to clarify this issue.

Second, except for the relevant liability and penalty rules as prescribed in Article 26, the law does not establish financial arrangements for compensation or remediation as a result of the contractor's failure to perform certain obligations. All national laws studied here, including the Deep Seabed Law, have required a sponsored contractor to provide evidence or written undertaking as to the financial capacity at the application stage. Some countries expressly include their capacity for adequate compensation for any environmental damage related to this requirement. Several countries (Singapore, Fiji, Nauru, Tonga and Tuvalu) follow this through with required financial guarantees or security after licence/sponsorship has been granted, so as to address potential damage or take measures toward rectifying the contractor's potential failure to fulfil its obligations. ${ }^{59}$ Fiji, Nauru, Tonga and Tuvalu may require a sponsored party to deposit a security as a guarantee of performance concerning its obligations or rectify any damage or loss caused as a result of failure to perform certain obligations. ${ }^{60}$ Tonga and Tuvalu further specify that the security may be used for clean-up or compensation costs in respect of any damage caused by pollution or other incidents occurring as a result of seabed mineral activities. ${ }^{61}$ The absence of the funds and security provisions in China's Deep Seabed Law may, therefore, render the controlling function of the law less effective or enforceable. Similar inadequacies also exist in other provisions of the law such as the

areas, including estimates of the components, quantity, distribution and economic value of resources".

57 ISA Regulations, supra note 40.

58 Polymetallic Sulphides Regulations, supra note 41, at Regulation 2.

59 ISA comparative study, supra 27 , at para.71.

6o Id.

$61 \quad I d$. 
elaboration on "deep sea public platform", and the uncertainty as to whether foreign investment is allowed to engage in China's deep seabed activities in the Area. All of these should be supplemented by more specific and detailed implementing regulations, administrative orders or judicial interpretations in the future.

The Deep Seabed Law was effective from 1 May 2016 and has only been in force for a few years. Thus far, it has been implemented by three administrative regulations pertaining to licensing, sample management, and data and information management, respectively. The first implementing regulation, "Measures for the Management of Permits on the Exploration and Development of Resources in Deep Seabed Areas", was promulgated on 27 April 2017.62 The "Interim Measures for the Management of Marine Samples from Exploration and Development of Resources in Deep Seabed Areas", 63 as well as the "Interim Measures for the Management of Data on the Exploration and Development of Resources in Deep Seabed Areas" were issued by the SOA on 29 December $2017,{ }^{64}$ as two further supplementary regulations to the Deep Seabed Law. Moreover, a national policy paper, the "13th Five-Year Plan for Exploration and Development of Deep Seabed Resources" was jointly issued by the State Oceanic Administration, the Ministry of Foreign Affairs, the Development and Reform Commission, the Ministry of Science and Technology, the Ministry of Finance, and the Ministry of Land and Resources on 16 April 2017. The paper stipulates that, during the 13th Five-Year Plan period (2016-2020), deep-sea ocean development work shall be guided by the goal of "building a maritime power"; it shall actively promote major engineering projects; and it shall further enhance China's capabilities in relation to resources investigation, exploration, development, and environmental protection. As one of the four major engineering projects in the marine field, "Jiaolong Exploration of the Sea" (蛟龙探海) is of significant importance toward advancing China's scientific and technological ability, and safeguarding Chinese entities' rights and interests in the deep-sea areas.

62 海洋局关于印发《深海海底区域资源勘探开发许可管理办法》的通知 [Announcement from the SOA on the issuance of the 2017 Implementing Regulation on Licensing], http://www.gov.cn/gongbao/content/2017/content_5227831.htm.

63 海洋局关于印发《深海海底区域资源勘探开发样品管理暂行办法》的通知 [Announcement from the SOA on the issuance of the 2017 Implementing Regulation on Management of Marine Samples], http://www.gov.cn/gongbao/content/2018/con tent_5299621.htm.

64 海洋局关于印发《深海海底区域资源勘探开发资料管理暂行办法》的通知 [Announcement from the SOA on the issuance of the 2017 Implementing Regulation on Management of Data], http://www.comra.org/2018-01/o4/content_40131061.htm. 
The forth implementing regulation, "Measures for the Environmental Investigation and Assessment of Resources in Deep Seabed Areas", is still in the pipeline and plans to be rolled out in 2020. Thus, it is yet to be determined what impact the Deep Seabed Law and its implementing regulations might have on China's domestic legal system, especially in relation to issues of environmental protection.

Moreover, China is a State committed to contributing to the international legal order by adhering to the rules of international law. The dual-track licensing approval mechanism means a contractor benefiting from China's State sponsorship is subject to both international and national rules. Using a domestic law to govern activities of Chinese citizens, juridical persons or organisations in an area outside the territorial waters of any nation describes an approach that is new to the Chinese administration. It remains to be seen how this arrangement will actually impact the behaviour of the industry, given the SOA and Chinese judicial authorities need to fully consider the relevant international rules, cooperate with the ISA, and understand the limits of their functions and powers.

Nevertheless, the Deep Seabed Law, in many aspects, represents a legal innovation by Chinese legislators and may serve as a guiding reference for other States wishing to engage in mining activities in the Area. China's Deep Seabed Law is an indispensable part of the overall comprehensive legal regime concerning the world's oceans and seas. It enshrines the notion that all problems related to ocean space are closely interrelated and need to be addressed in a holistic manner. 